Tropical Agricultural Research \& Extension 19 (3): 2016

\title{
EFFECT OF GOOD GOVERNANCE PERCEPTION TOWARDS JOB SATISFACTION: A CASE STUDY OF THE AGRICULTURE PROFESSIONALS ATTACHED TO THE DEPARTMENT OF AGRICULTURESRI LANKA
}

\author{
AL Sandika ${ }^{*}$, LP Rupasena $^{2}$ and LM Abeywickrama ${ }^{1}$ \\ ${ }^{1}$ Department of Agricultural Economics and Extension, Faculty of Agriculture, University of Ruhuna, \\ Mapalana, Kamburupitiya, Sri Lanka \\ ${ }^{2}$ Department of Agricultural Systems, Faculty of Agriculture, Rajarata University of Sri Lanka, Puliyanku- \\ lama, Anuradhapura, Sri Lanka
}

\begin{abstract}
Effectiveness of service delivery system of public sector organizations like Department of Agriculture (DoA) depends on the job satisfaction of the relevant officers. Research Officers (ROs), Agriculture Officers (AOs), Lecturers (LCs) and Subject Matter Specialists (SMSs) are the key officers in the DoA in Sri Lanka Agriculture Service (SLAgS). It is therefore, a pre requisite to improve the job satisfaction of SLAgS officers in the DoA in order to improve the effectiveness of service delivery system. Further, empirical evidence showed that there was a positive relationship between good governance (GG) and job satisfaction. On the other hand, personal and job related factors are also affect job satisfaction of the employees. This study therefore attempted to identify how job satisfaction can be improved via improving good governance perception and other factors of officers of SLAgS working in the DoA. Pre tested questionnaire was used to collect the data from ROs, AOs, LCs and SMSs. Results of the correlation test showed that there was a positive and significant relationship between job satisfaction and GG perception of SLAgS officers $(r=0.673, p=0.001)$. It reveals that the favourable GG perception of the employees increased their job satisfaction. In addition, path analysis was performed to identify the direct and indirect factors which positively or negatively influence the GG perception and job satisfaction of the respondents. According to the Path analysis, there was a direct effect of GG perception to job satisfaction and indirect effect of other factors to job satisfaction through GG perception.
\end{abstract}

Key words: Department of Agriculture, SLAgS officers, good governance, job satisfaction, path analysis

\section{INTRODUCTION}

Implementing of good governance practices in the public sector organizations are broadly discussed at present. Mohamad et al., (2014) pointed out that, at present, high expectation and more educated civil society especially who live in the urban area, are expecting high performance by the public sector organizations through good governance. Siddiquee, (2009) showed that public sector organizations have to improve and strengthen the values of good governance regularly in order to perform their excellent service delivery to public. In human resource perspective, the employees are considered to be the source of good governance success. Shahin (2016) has studied about the effect of good governance in governmental organizations on promotion of employees' job

\footnotetext{
*Corresponding author: sandika@agecon.ruh.ac.lk
}

satisfaction. The results of this study have shown that there is a significant positive relationship between good governance and job satisfaction. It implies that job satisfaction and performance can be improved by implementation of good governance in the organization, However, understanding of job satisfaction is difficult. James and Jone (1980) pointed out that job satisfaction is an affective or emotional attitude of an individual towards his or her job while Hopkins (1983) said that it is a general attitude about a job and some particular aspects of their job or gratification of certain needs that are associated with ones work. Luthans (2002) pointed out that there are three dimensions to job satisfaction such as emotional response to a job, how outcomes meet or exceed expectations and job satisfaction related to attitudes of the worker. It is a posi- 
tive emotional state. Therefore, it cannot be seen but it can only be inferred. The perception of job satisfaction depends on the intrinsic and extrinsic properties of the job and characteristics of the individual employee (Kalleberg, 1977). Job satisfaction therefore, is a function of many factors which have direct or indirect effect.

On this context, effectiveness of service delivery system of public sector organizations like Department of Agriculture (DoA) depends on the job satisfaction of the relevant officers. Research Officers (ROs), Agriculture Officers (AOs), Lectures (LCs) and Subject Matter Specialists (SMSs) are the key officers in the DoA and they belong to the Sri Lanka Agriculture Service (SLAgS). At present their designations have been revised as Assistant Director of Agriculture Research or Extension. The DoA is functioning under the Ministry of Agriculture. Head of the DoA is Director General (DG) and there are three Additional Director Generals and fourteen directors who are responsible for the different disciplines such as Rice Research and Development, Field Crops Research and Development, Horticulture Crop Research and Development, Extension and Training Centre, Seed Certification and Plant Protection Centre, Seed and Planting Material Development Centre, Socio Economics and Planning, Administration and Finance in the DoA.

Further, there is no sufficient empirical evidence regarding the relationship of GG perception and other variables toward the job satisfaction by agricultural professionals working in the Department of Agriculture. On this background, this study attempted to recognize the effect of GG perception toward the job satisfaction of SLAgS officers working in the Department of Agriculture with specific objectives such as to assess the good governance perception and job satisfaction by SLAgS officers working in the DoA, to determine, how GG perception and other personal and job related factors influence the job satisfaction of SLAgS officers in DoA by applying the Path analysis.

\section{METHODOLOGY}

Department of Agriculture (DoA) was selected as study organization from which both primary and secondary data were collected for the study. Primary data were directly collected from the SLAgS officers in the DoA. Further, secondary data were collected from published sources such as Administration Reports, Annual Reports, Research Papers, Circulars and unpublished sources. A draft questionnaire was initially structured based upon objectives and information requirements for this study. Afterward, pre tested questionnaire was used to collect the data from the respondents. Eighty three ROs, thirty three AOs and twenty Lecturers and four SMSs were selected to form a sample of 140 by using proportionate random sampling techniques. However, data of the lecturers and SMSs were merged together due to insufficient number of questionnaires received from the SMS. Further, two questionnaires was filtered out because improper filling of the information by the respondents. Therefore, final sample size was 138. Good governance perception, job satisfaction and other demographic and job related variables such as age, education, gender, job experience, training and visits, information seeking behaviour, satisfaction about job title, job description, perceived workload, job involvement, job stress, job freedom, facilities and resources at work and health condition were taken as the variables.

IMF (2007) stated that good governance has eight major characteristics such as participation, consensus orientation, accountability, transparency, responsiveness, effectiveness and efficiency, equitability and inclusiveness and follows the rule of law. Shahin (2016) has used above indicators and aspects of good governance more carefully, to investigate and evaluate organizational level as smaller level. Albritton and Bureekul (2009) have developed a scale to measure the attitudes on "good governance" by conceptualization of eight dimensions of good governance. By following the same procedures, good governance perception of SLAgS officers was measured by using the scale especially developed for this study with 28 items representing eight dimensions. This scale was a fivepoint Likert-scale with weightage of $+2,+1,0$, -1 and -2 respectively for most favourable, fa- 
vourable, neutral, unfavourable and most unfavourable responses for the statements. Finally, three main categories viz. less favourable, favourable and most favourable category were made based on the total value of the Likert scale.

To assess the level of job satisfaction, Herzberg's theory (1968) was adopted. According to 'Herzberg, there are two dimensions use for job satisfaction such as motivation and hygiene. The similar idea for the job satisfaction was given by the Newstrom and Davis, (2004). This variable was quantified by using a scale developed by Manjula (2000) followed by Sandika et al., (2007). The scale consisted of 15 statements expressing different aspects of job satisfaction which belonged to either hygiene factors or motivators. Each of these statements had Likert-scale with five point viz., from highly satisfied to highly dissatisfy with scores of $+2,+1,0,-1$ and -2 score, respectively. Then job satisfaction score of a respondent was obtained by summing up the scores obtained by him/her on all the statements.

Further, principle component analysis (PCA) was employed to select the suitable statements. Before the PC analysis was performed, validity and reliability of the questionnaire were measured. To enhance validity of the instrument pre-testing was done with the target population. Similar procedure has followed by Muindi (2014). Coefficient alpha also known as Cronbach alpha was used to assess the reliability of a multiple item variable, (Zebal, 2003).

Descriptive statistics such as frequencies and percentages were used at the beginning of the analysis. Further, non-parametric and parametric statistical tools such as chi-square and simple correlation were used to test the statistical significance by employing SPSS software. Path analysis was also done to identify the direct and indirect effects of factors which positively or negatively influence the GG perception and job satisfaction of the SLAgS officers. Garson (2005) explained that path analysis is an extension of the regression model which can be used to test the fit of the correlation matrix against two or more causal models which are being compared by the researcher. The model is usually depicted in a circle and arrow figure in which single headed arrows indicate causation.

\section{RESULTS AND DISCUSSION}

Cronbach's alpha value related to reliability test for the Likert scale of Good Governance (GG) perception was $0.936(\mathrm{p}=\mathrm{o} . \mathrm{oo})$ which means that reliability of scale is excellent. Principle Component Analysis (PCA) was performed to identify the major components of statements which were suitable to measure the GG in the DOA. According to the KMO and Bartlett's Test value of the sampling adequacy determined as $0.884(\mathrm{p}=0.00)$. This was very high value. Further, variables with coefficient of 0.45 or more were regarded to have significant loadings and all the statements were selected for the further analysis. Further, it was observed that results of the KMO and Bartlette's were high for the job satisfaction sale. Value of this test was 0.868 $(\mathrm{p}=0.00)$.

Further, variables with coefficient of 0.45 or more were considered and all the statements were selected for the further analysis. Moreover, PCA proved that all the statements can be used to measure the job satisfaction. Secondly, Cronbach's alpha value related to reliability test for the Likert scale of job satisfaction was 0.892 . It indicates that reliability of scale adopted to measure job satisfaction is high.

Table 2, shows that $69 \%$ of the total sample perceived the GG in the DOA as favourable, while $27 \%$ and $04 \%$ of them perceived it as most favourable and less favourable, respectively. It was further observed that majority of ROs (64\%) AOs (70\%) and LCs (86\%) perceived the GG as favourable, whereas the

Table 1: Reliability Statistics

\begin{tabular}{lll}
\hline Scale & $\begin{array}{l}\text { Cronbach' } \\
\text { S Alpha }\end{array}$ & $\begin{array}{l}\text { No. of } \\
\text { Items }\end{array}$ \\
\hline $\begin{array}{l}\text { Good Governance } \\
\text { Perception }\end{array}$ & 0.936 & 28 \\
Job Satisfaction & 0.892 & 15 \\
\hline
\end{tabular}


most favourable perception was observed with $31 \%$ of ROs and $27 \%$ of AOs and $09 \%$ of lecturers. It brings home the fact that majority of SLAgS functionaries viz., ROs, AOs and LCs were satisfied and highly satisfied with GG in the Department of Agriculture.

The data presented in Table 3 revealed that majority of the respondents of the total sample $(73.00 \%)$, ROs $(61.00 \%)$, AOs $(70.00 \%)$, and LCs $(73.00 \%)$ were in the category of not satisfied to highly dissatisfied level whereas, $27.00 \%$ of ROs and $30.00 \%$ of AOs 27.00 $\%$ of lecturers were observed in satisfaction to high job satisfaction level. Here the chi square test results indicate the significance of association between Job satisfaction and job category. This finding are in agreement with the findings of Bosco (2000), Nagananda (2005),
Sandika, and Kalansuriya (2014), Widisinghe and Sandika (2015).

Results of the study further revealed that negative responses have received for the present salary for the commensurate with their work and position $(-0.23)$, paid salary related to educational qualification (-0.29), performance assessment methods (-0.14), distance from office to house $(-0.17)$, facilities availability ($0.14)$, recognition and reward for their creative work (-0.19), opportunities for higher education and training (-0.26), flexibility to engage with family responsibilities, children's' education etc. (0.00) and availability of promotion according to performance $(-0.28)$. It mean that majority of SLAgS officers were in the dissatisfy level or not satisfy level regarding above indicated job satisfaction dimen-

Table 2: Good Governance perception of ROs, AOs and LCs $\quad(n=138)$

\begin{tabular}{ccccc}
\hline \multirow{2}{*}{ Categories } & ROs & AOs & Lecturers & Total \\
\cline { 2 - 5 } & No. (\%) & No. $(\%)$ & No. (\%) & No. (\%) \\
\hline Less favourable & $4(5 \%)$ & $01(3 \%)$ & $01(5 \%)$ & $6(04 \%)$ \\
$\begin{array}{l}\text { Favourable } \\
\text { More favourable }\end{array}$ & $53(64 \%)$ & $23(70 \%)$ & $19(86 \%)$ & $95(69 \%)$ \\
\hline \multicolumn{1}{c}{ Total } & $26(31 \%)$ & $09(27 \%)$ & $02(09 \%)$ & $37(27 \%)$ \\
\hline$X^{2}$ & $83(100 \%)$ & $33(100 \%)$ & $22(100 \%)$ & $138(100 \%)$ \\
\hline
\end{tabular}

** Significant at $1 \%$ level

Table 3: Good Governance perception of ROs, AOs and LCs $\quad(n=138)$

\begin{tabular}{lllll}
\hline \multirow{2}{*}{ Satisfaction } & \multicolumn{5}{c}{ Job category } \\
\cline { 2 - 5 } & \multicolumn{1}{c}{ ROs } & AOs & Lecturers & Total \\
\hline \multirow{2}{*}{$\begin{array}{l}\text { Highly dissatisfy Dissat- } \\
\text { isfied }\end{array}$} & $4(05 \%)$ & $1(03 \%)$ & $0(00 \%)$ & $6(04 \%)$ \\
Not satisfied & $21(25 \%)$ & $7(21 \%)$ & $02(09 \%)$ & $32(23 \%)$ \\
Satisfied & $36(43 \%)$ & $15(46 \%)$ & $14(64 \%)$ & $63(46 \%)$ \\
Highly satisfied & $18(22 \%)$ & $6(18 \%)$ & $6(27 \%)$ & $29(21 \%)$ \\
& $4(05 \%)$ & $4(12 \%)$ & $0(00 \%)$ & $8(06 \%)$ \\
\hline Total & & & & $138(100 \%)$ \\
\hline \multicolumn{1}{c}{$\mathrm{X}^{2}$} & $83(100 \%)$ & $33(100 \%)$ & $9.3 * *$ \\
\hline
\end{tabular}

$7 * *$ Significant at $1.00 \%$ level. *Values within parenthesis are percentages 
sions. According to Motivator- Hygiene Theory those were belonged to Hygiene factors. It is further important to point out that when the absent of the hygiene factors within the organization lead the dissatisfaction of the employment. On the other hand, it will be the cause of the de-motivation. Similar result has been found by Sandika and Silva (2011) for their study.

Nevertheless, positive responses have been obtained for the guidance given by superiors to improve their job (0.36), freedom and flexibility for carrying out the job (0.54), opportunities to utilize their personal skill (0.32) and mutual understanding with the co-workers $(0.70)$. These points related to the motivator, and majority SLAgS officers satisfied about the motivator available at the DOA.

Nmai and Delle (2014) have applied Pearson Product-Moment correlation test to test the relationship of governance perception with the level of job satisfaction. Their result showed that corporate governance significantly and positively predicted employee job satisfaction. The results of Pearson ProductMoment correlation test between job satisfaction of ROs, AOs and LCs with their GG perception are presented in Table 4 which indicated that there was a positive and significant relationship between job satisfaction and GG perception of SLAgS officers. Hence, it can be concluded that the favourable GG perception of the employees increased their job satisfaction. Therefore, it is a 'must' to maintain the principle of GG in the DOA to increase the job performance of the employees. Findings of this study fully agreed with the findings of Ott (2010), Nmai and Delle (2014) and Shahin (2016).

Table 5 illustrates that the Information Seeking Behaviour, Job title, TOR, Awareness of TOR, satisfaction about TOR, relates of TOR with job expectation, job involvement, job freedom, facilities and resources available for carrying out jobexhibited positive and significant relationship with $\mathrm{GG}$ perception of ROs, whereas, age, present job experience, trainings, health perception, similarity TORandduties and job stress showed negative significant relationship with GG perception of the ROs. Gender, distance from home to workplace, transport mode, SLAgS class, education, job experience, and perceived work load did not show any relationship with the Good Governance perception of ROs.

Seven variables namely age, job experience, training, ISB, job stress, job freedom and facilities and resources available for carrying out job exhibited significant relationship with GG perception among AOs. Out of them age, job experience, training received and job stress were shown negative significant relationship with GG perception. Further, other variables such as gender, transport mode, education, information seeking behaviour, health, Job title, TOR, awareness of TOR, satisfaction about TOR, workload, job stress and job in-

Table 4: Correlation of independent variables with the GG perception and job satisfaction

\begin{tabular}{ll}
\hline Group & Correlation coefficient \\
\hline Total Sample & $0.673^{* *}$ \\
ROs & $0.739^{* *}$ \\
AOs & $0.683^{* *}$ \\
Lecturers & $0.597^{* *}$ \\
\hline
\end{tabular}

volvement did not show any relationship with the Good Governance perception of AOs .

Only three variables namely ISB, and facilities and resources available for carrying out job were shown positive and significant relationship while job involvement were illustrated negative relationship with the GG perception of LCs.

SLAgS class, ISB, Health, Job title, TOR, Awareness of TOR, satisfaction about TOR, relates of TOR with job expectation, job involvement, job freedom, facilities and resources available for carrying out job exhibited positive and significant relationship with job satisfaction while education and job stress negatively and significant relationship with job satisfaction of ROs.

ISB, relates of TOR with job expectation, job freedom, facilities and resources available for carrying out job shown positive and signifi- 
269 SANDIKA AL ET AL: EFFECT OF GOOD GOVERNANCE TOWARDS JOB SATISFACTION OF AGRICULTURE PROFES-

Table 5: Correlation of Independent Variables with GG Perception and Job Satisfaction

\begin{tabular}{|c|c|c|c|c|c|c|c|}
\hline \multirow{2}{*}{$\begin{array}{l}\text { SI. } \\
\text { No. }\end{array}$} & \multirow{2}{*}{$\begin{array}{l}\text { Independent } \\
\text { variables }\end{array}$} & \multicolumn{3}{|c|}{ GG Perception } & \multicolumn{3}{|c|}{ Job satisfaction } \\
\hline & & ROs & $A O s$ & $L C s$ & ROs & AOs & $L C s$ \\
\hline 1. & Age & $-0.24 *$ & $0.24 *$ & $-0.08^{\mathrm{NS}}$ & $-0.00^{\mathrm{NS}}$ & $0.07^{\mathrm{NS}}$ & $-0.04^{N S}$ \\
\hline 2. & Gender & $-0.17^{\mathrm{NS}}$ & $-0.11^{\mathrm{NS}}$ & $-0.01^{\mathrm{NS}}$ & $-0.08^{\mathrm{NS}}$ & $-0.18^{\mathrm{NS}}$ & $-0.11^{\mathrm{NS}}$ \\
\hline 3. & Distance & $0.14^{\mathrm{NS}}$ & $-0.05^{\mathrm{NS}}$ & $-0.26^{\mathrm{NS}}$ & $-0.09^{\mathrm{NS}}$ & $-0.13^{\mathrm{NS}}$ & $-0.15^{N S}$ \\
\hline 4. & Transport Mode & $-0.09^{\mathrm{NS}}$ & $0.09^{\mathrm{NS}}$ & $0.03^{\mathrm{NS}}$ & $0.15^{\mathrm{NS}}$ & $0.14^{\mathrm{NS}}$ & $-0.36^{\mathrm{NS}}$ \\
\hline 5. & SLAgS Class & $0.16^{\mathrm{NS}}$ & $-0.16^{\mathrm{NS}}$ & $0.26^{\mathrm{NS}}$ & $0.21 *$ & $-0.25^{\mathrm{NS}}$ & $0.39^{\mathrm{NS}}$ \\
\hline 6. & Education & $0.04^{\mathrm{NS}}$ & $0.02^{\mathrm{NS}}$ & $-0.07^{\mathrm{NS}}$ & $-0.22 *$ & $-0.33^{*}$ & $-0.17^{\mathrm{NS}}$ \\
\hline 7. & Job experience & $-0.27^{*}$ & $0.36^{*}$ & $-0.20^{\mathrm{NS}}$ & $0.03^{\mathrm{NS}}$ & $0.31^{\mathrm{NS}}$ & $-0.05^{\mathrm{NS}}$ \\
\hline 8. & Training & $-0.33 * *$ & $0.33 *$ & $-0.33^{\mathrm{NS}}$ & $0.01^{\mathrm{NS}}$ & $0.04^{\mathrm{NS}}$ & $-0.15^{\mathrm{NS}}$ \\
\hline 9. & ISB & $0.35 * *$ & $0.35^{* *}$ & $0.41 *$ & $0.4 * *$ & $0.4 * *$ & $0.21^{\mathrm{NS}}$ \\
\hline 10. & Health & $-0.23 *$ & $0.31^{\mathrm{NS}}$ & $0.14^{\mathrm{NS}}$ & $0.27 *$ & $0.11^{\mathrm{NS}}$ & $0.10^{\mathrm{NS}}$ \\
\hline 11. & Job Title & $0.32 * *$ & $-0.06^{\mathrm{NS}}$ & $-0.11^{\mathrm{NS}}$ & $0.33 * *$ & $0.27^{\mathrm{NS}}$ & $.50 *$ \\
\hline 12. & TOR & $0.31 * *$ & $-0.08^{\mathrm{NS}}$ & $-0.20^{\mathrm{NS}}$ & $0.24 *$ & $-019^{\mathrm{NS}}$ & $-0.15^{\mathrm{NS}}$ \\
\hline 13. & Awareness about TOR & $0.30 * *$ & $-017^{\mathrm{NS}}$ & $-0.20^{\mathrm{NS}}$ & $0.37 * *$ & $-0.19^{\mathrm{NS}}$ & $0.32^{\mathrm{NS}}$ \\
\hline 14. & Satisfaction about TOR & $0.36 * *$ & $0.01^{\mathrm{NS}}$ & $0.24^{\mathrm{NS}}$ & $0.48 * *$ & $0.29^{\mathrm{NS}}$ & $0.38^{\mathrm{NS}}$ \\
\hline 15. & $\begin{array}{l}\text { Relates of TOR with job } \\
\text { expectation }\end{array}$ & $0.41 * *$ & $0.13^{\mathrm{NS}}$ & $0.15^{\mathrm{NS}}$ & $0.48 * *$ & $0.53 * *$ & $-0.02^{\mathrm{NS}}$ \\
\hline 16. & Similarity TOR and duties & $-0.24 *$ & $0.23^{\mathrm{NS}}$ & $0.03^{\mathrm{NS}}$ & $-0.06^{\mathrm{NS}}$ & $-0.22^{\mathrm{NS}}$ & $0.07^{\mathrm{NS}}$ \\
\hline 17. & Perceived workload & $0.254 *$ & $0.02^{\mathrm{NS}}$ & $0.09^{\mathrm{NS}}$ & 0.29 & $0.25^{\mathrm{NS}}$ & $-0.21^{\mathrm{NS}}$ \\
\hline 18. & Job involvement & $0.30 * *$ & $-0.11^{\mathrm{NS}}$ & $-0.56 * *$ & $0.20^{\mathrm{NS}}$ & $0.19^{\mathrm{NS}}$ & $0.08^{\mathrm{NS}}$ \\
\hline 19. & Job stress & $-0.43 * *$ & $0.35^{*}$ & $0.41^{\mathrm{NS}}$ & $-0.25^{*}$ & $-0.25 * *$ & $-0.02^{\mathrm{NS}}$ \\
\hline 20. & Job freedom & $0.46^{* *}$ & $0.32 * *$ & $0.25^{\mathrm{NS}}$ & $0.5 * *$ & $0.50 * *$ & $0.12^{\mathrm{NS}}$ \\
\hline 21. & Facilities and resources & $0.55 * *$ & $0.47 * *$ & $0.43 * *$ & $0.69 * *$ & $0.69 * *$ & $0.40^{*}$ \\
\hline
\end{tabular}

* Significant at $5 \%$ level. ** Significant at $1 \%$ level. NS=Non-significant 
cant relationship with job satisfaction while education and job stress negatively and significant relationship with job satisfaction of AOs. Job title facilities and resources available for carrying out job exhibited positive and significant relationship with job satisfaction of LCs (Table 5).

Garson (2005) explained that path analysis is an extension of the regression model which can be used to test the fit of the correlation matrix against two or more causal models which are being compared by the researcher. So, path analysis was also done to identify the direct and indirect factors which positively or negatively influence the GG perception and job satisfaction of the SLAgS officers.

Good governance and availability of facilities showed direct causes for the job satisfaction while availability of facilities showed both direct and indirect causes to job satisfaction where indirect causes go through GG perception (Fig 1). According to this Path analysis, job satisfaction of the ROs can be improved through increasing facilities available and GG perception.

Further, job freedom and present job experience showed indirect causes to job satisfaction through availability of facilities. On the other hand, job title showed direct and indirect impact through GG perception to job satisfaction. Age showed indirect impact through GG perception to job satisfaction. And also, ISB, job stress and training show indirect impact to job satisfaction.

There is a direct causes of GG perception; availability of facilities and job freedom to the job satisfaction while indirect causes of availability of facilities, job freedom and trainings to the job satisfaction for the AOs (Fig. 2). Further, job stress and ISB show indirect causes to job satisfaction through GG perception to job satisfaction. On the other hand, age and present job experience show indirect impact through GG perception to job satisfaction. Ac-

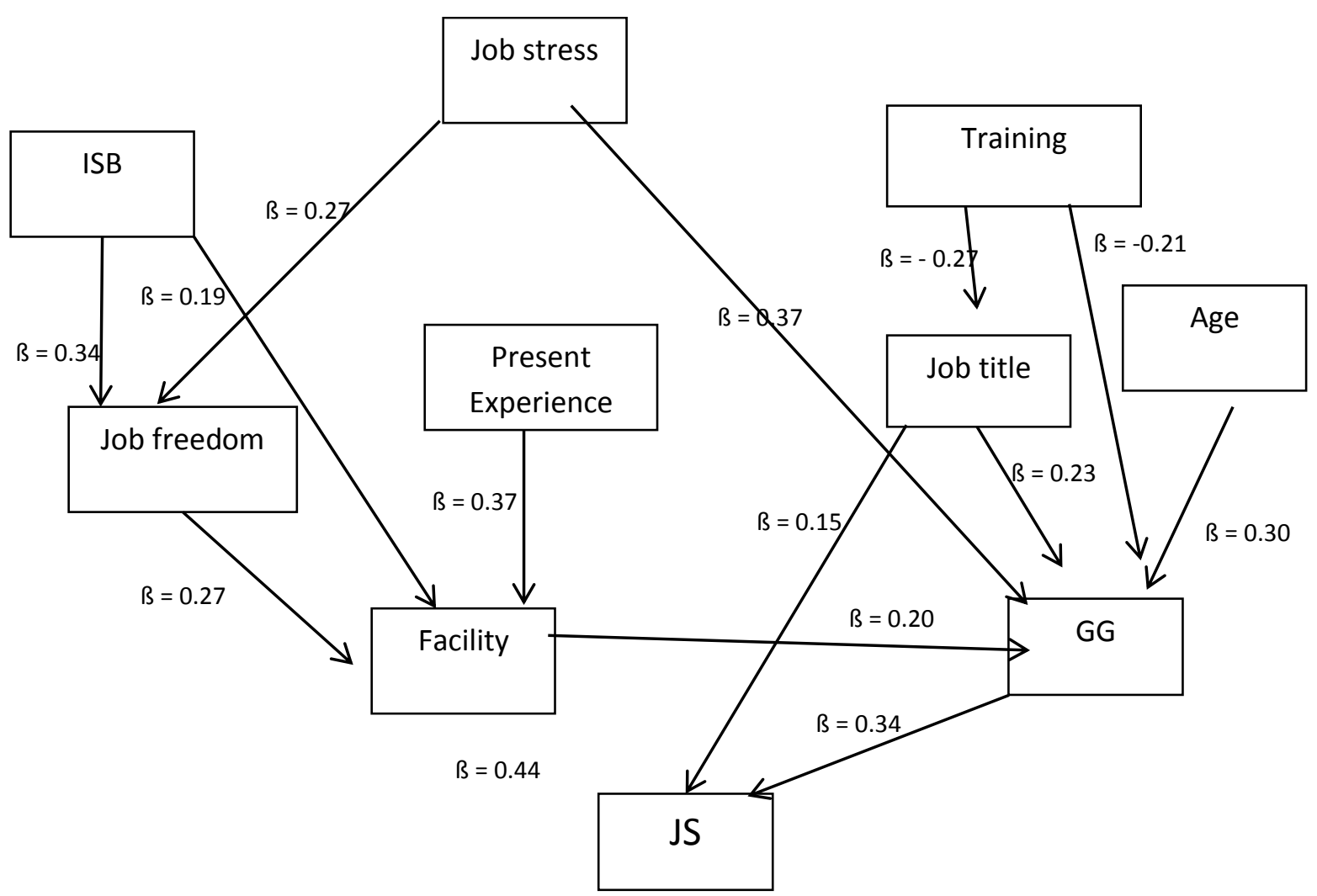

Figure 1: Path analysis for ROs 
cording to this path analysis, job satisfaction of the AOs can be increased by addressing above variables. Therefore, relevant officers and policy decision authorities should be taken in to consideration of silent features of this Path analysis.

The study revealed job satisfaction of Lecturers is a direct cause of GG perception and the job title (Fig 3). Further, availability of facilities and education show the indirect causes for the job satisfaction. Thus, the result of Path analysis shows that job satisfaction of the Lecturers can be improved through increasing facilities available, introducing attractive job title and GG perception.

\section{CONCLUSION}

We observed that $64 \%$ of Research Officers, $70 \%$ of Agriculture Officers and $86 \%$ of Lecturers perceived Good Governance (GG) in Department of Agriculture (DOA) as a favourable factor. Nevertheless, majority of the respondents were in the category of not satisfaction to highly dissatisfied regarding their job. The survey revealed that there was a positive and a significant relationship between job satisfaction and GG perception of SLAgS officers. It reveals that the favourable GG perception of the employees increase their job satisfaction. Based on the Path analysis, it was concluded that there were direct and indirect factors which positively or negatively influence the GG perception and job satisfaction of the respondents. Job satisfaction of the ROs can be improved through increasing facilities available and GG perception. Further, job freedom, ISB and present job experience shows indirect causes to job satisfaction through availability of facilities. On the other hand, job title shows direct and indirect impact through GG perception to job satisfaction. Age shows indirect impact through GG perception to job satisfaction. And also ISB, job stress and training shows indirect impact to job satisfaction.

There is a direct causes of GG perception, availability of facilities and job freedom to the job satisfaction while indirect causes of availability of facilities, job freedom and trainings to the job satisfaction for the AOs. Further job stress and ISB show indirect causes to job satisfaction through GG perception to job satis-

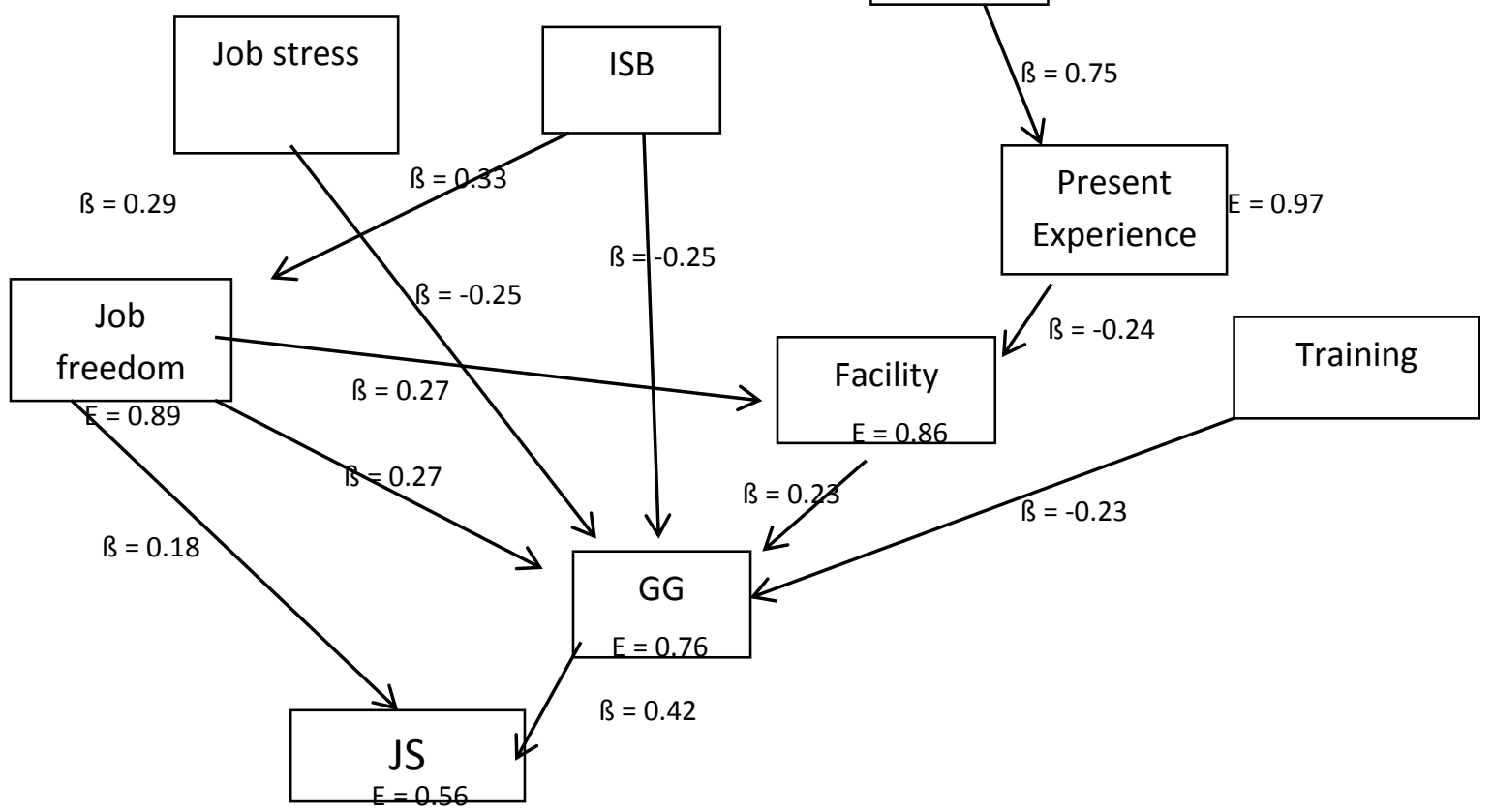

Figure 2: Path analysis for AOs 


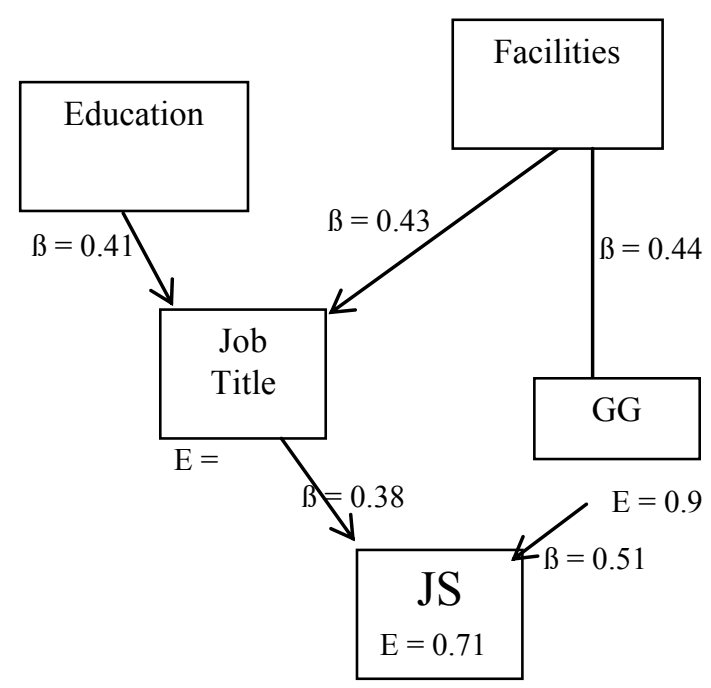

Figure 3: Path analysis for Lectures

faction. On the other hand, age and present job experience show indirect impact through GG perception to job satisfaction. Job satisfaction of the Lecturers is a direct cause of GG perception and the job title. Further, availability of facilities and education show the indirect causes for the job satisfaction. Therefore, relevant officers and policy decision authorities should take into consideration the results of this study and the salient features of the Path analyses.

It is suggested to identify ways to improve awareness on GG practices that can be done as a research. Consequently, institutional arrangements, financial and human resources capacities, public-private sector collaborations, and appropriate oversight mechanisms are very crucial in achieving objectives of the DoA. These points can be taken into consideration for future research. In terms of good governance, it was noted in this study that there were many issues such as leadership style, public participation, financial and human resources management, government policy changes and the impact of decentralization etc. that have an influence on good governance practices and service delivery, some of which need further research in order to provide answers and contribute to constant public administration growing body of knowledge. There is an urgent need to con- sider experimental or longitudinal studies to reveal the actual cause of the connection or long-term effect of good governance.

\section{REFERENCES}

Ramanie KH, Baker JH and Baker AV 2008 Benefits of mycorrhizae to soybeans grown on various regimes of nitrogen nutrition, Journal of Plant Nutrition, Retrieved September 3, 2012, From www.tandfonline.com

Albritton RB and Bureekul T. 2009. Are Democracy and "Good Governance" Always Compatible, Competing Values in the Thai Political Arena, Working Paper Series: No. 47, Asian Barometer Project Office, Department of Political Science of National Taiwan University and Institute of Political Science of Academia, Chile.

Bosco K. 2000 Study on job performance and job satisfaction of Assistant Agricultural Officers in Northern Districts of Karnataka, M.Sc. (Agri.) Thesis, University of Agricultural Sciences, Dharwad.

Garson D. 2005 Path Analysis, Lecture Notes, 2005, Professor of Public Administration, North Carolina State University, Raleigh, North Carolina.

Herzberg Frederick.1968. "One More Time: How Do You Motivate Employees?" Harvard Business Review 46::53-62.

Hopkins AH. 1983 Work and job satisfaction in the public sectors. Rowman and Allonheld Publishers.

IMF. 2007. Manual on Fiscal Transparency, IMF, Washington DC, Glossary. http:// www.imf.org/external/pubs.

James LR and Jone AP. 1980 Perceived job characteristics and job satisfaction: An examination of reciprocal causation, Journal Personnel psychology, 33: 97 - 135.

Kalleberg AL. 1977 Work values and job rewards: A theory of job satisfaction. American Social Review, 42: 124 - 143.

Luthans F. 2002 Organizational Behaviour, McGraw Hell India. P $141-144$.

Manjula N. (2000). A study on job perception, job performance and job satisfaction of AAOs in Karnataka.Ph.D Thesis University of Agricultural Sciences, Bangalore. P 178-183.

Mohamad MH, Daud Z and Yahya KKM. 2014 Impact on employees' good governance characteristics, the role of transformational leadership as determinant factor International 
Journal of Science, Environment and Technology, 3 (1): $320-338$.

Muindi KM. 2014 Influence of governance practices on employee job satisfaction at teachers service commission headquarters Nairobi, Kenya. Master Thesis. Master of Education in Corporate Governance, University of Nairobi.

Nagananda C. 2005. Study of organizational climate perception of Assistant Directors of Agriculture and Agricultural officers of KSDA, Master Thesis, University of Agricultural Sciences, Dharwad.

Newstrom JW and Davis K. 2004 Organizational Behaviour, Human behavior at work, Tata McGraw Hill Publishing Company Limited, New Delhi.

Nmai BN and Delle E. 2014. Good Corporate Governance and Employee Job Satisfaction: Empirical Evidence from the Ghanaian Telecommunication Sector, International Journal of Humanities and Social Science Vol. 4 (13) 212-217.

Ott CJ. 2010 Good Governance and Happiness in Nations: Technical Quality Precedes Democracy and Quality Beats Size, Journal of Happiness Studies, 11 (3): 353-368.

Sandika AL. Angady JG. Hirevenkanagoudar LV and Basavaraj H. 2007 A Study on Organizational Climate Perception by Veterinary Officers and Veterinary Livestock Inspector of Department of Animal Husbandry and Veterinary Service, Karnataka. Journal of Agricultural Sciences, 3(2): 75-81.

Sandika A. and Kalansuriya NK. 2014 Job satisfaction of agriculture graduates working under government graduate scheme, Journal of Tropical Agricultural Research and Extension $16(2)$

Sandika AL and Silva KNND. 2011 Relationship between Job Satisfaction and Organizational Climate: The Case of Agricultural Instructors (AIs) of the Department of Agriculture in Southern Province, Proceedings of the $8^{\text {th }}$ International Conference on Business Management, Faculty of Management Studies and Commerce, University of Sri Jayewardenepura. $1-8$.

Shahin M. 2016 The Effect of Good Governance Mixture in Governmental Organizations on Promotion of Employees' Job Satisfaction (Case Study: Employees and Faculty Members of Lorestan University) Asian Social Science; Vol. 12, (5).

Siddiquee NA. 2009 Service delivery innovations and governance: The Malaysian experience.
Journal of Transforming Government: People, Process and Policy, Vol. 2 (3), 194-213.

Widisinghe SD and Sandika AL. 2015 Job satisfaction of extension officers: a case study in a private organization, Journal of Tropical Agricultural Research and Extension 18 (4), 159-162

Zebal MA. 2003 A Synthesis model of market orientation for a developing country. The case of Bangladesh, Doctors dissertation, Victoria University of technology, Melbourne. 